\title{
Innovations in Agritourism: Evidence from a Region in Poland
}

\author{
Michał Roman ${ }^{1, *}$ (]) Monika Roman ${ }^{1}\left[\right.$ and Piotr Prus ${ }^{2}$ (I) \\ 1 Institute of Economics and Finance, Warsaw University of Life Sciences, 02-787 Warsaw, Poland; \\ monika_roman@sggw.edu.pl \\ 2 Laboratory of Economics and Counseling in Agribusiness, Department of Agronomy, Faculty of Agriculture \\ and Biotechnology, UTP University of Science and Technology in Bydgoszcz, 85-790 Bydgoszcz, Poland; \\ piotr.prus@utp.edu.pl \\ * Correspondence: michal_roman@sggw.edu.pl
}

Received: 9 May 2020; Accepted: 12 June 2020; Published: 14 June 2020

check for updates

\begin{abstract}
The objective of the article is to present the study of agritourism innovativeness. The analysis covers agritourism farms in Poland. It is also essential to identify the factors affecting the process of implementing innovation in agritourism. The objective of the article is to formulate conclusions on the impact of innovations on the development of agritourism and the competitiveness of agritourism farms that can be used by representatives of various agritourism-supporting institutions and organizations. A diagnostic survey-study was conducted in 2018, applying a survey questionnaire with a sample of 81 self-employed agritourism farm owners. Ward's hierarchical clustering method was applied to group the counties in terms of innovativeness. For this purpose, the data provided by the central statistics authority (GUS) and the authors' own survey study were used. The study confirms, e.g., the key significance of innovation for the development of agritourism in the counties analyzed. Additionally, in the article there is developed an original farm's competitive positioning index and gaining a competitive advantage on the agritourism services market, with three farms in Germany, France and Poland, respectively as an example.
\end{abstract}

Keywords: rural areas; rural tourism; farm; cluster analysis; Ward's method

\section{Introduction}

As for many rural areas, agritourism is one of the key rural development factors [1,2]. It has an impact on the development of rural areas, which is important in the socioeconomic policy of the European Union countries [3-5]. A literature review demonstrates a lack of agreement about the definition of the term. For the purpose of this article, it is assumed that

"agritourism is a part of rural tourism referring to leisure, including active leisure, for the plural of person is people on an operating agricultural farm which offers various recreational and tourist services on the farm and outside it, in high season or throughout the calendar year" [6].

The most important agritourism development conditions are rural areas' attractiveness, as well as a favorable pattern of natural aspects, social and economic qualities, which is stressed by Wojtkowiak [7]: “ $(\ldots)$ a region which is attractive in terms of tourist qualities is a product of nature and the human activity, while the right use of those qualities can be a springboard for a development of the region or the entire commune".

The impact of agritourism on the development of the rural areas is a complex problem [8]. One of the grounds is an assumption that booming agritourism services enhance the operation of other 
economic entities in the rural areas and often trigger the emergence of new enterprises targeted at satisfying the needs of the tourists [7].

Agritourism is one of the few forms of non-agricultural activity which triggers the development of agriculture by creating a favorable market for agricultural products and, due to the room rental and rendering the services for the guests, it increases the farmer's personal income [7]. It is an integral element of sustainable development of the rural areas [9-11]. It facilitates an optimal use of the nature's qualities and, at the same time, solves important problems of the rural population [12]. It creates an opportunity for job activation in the rural region as launching such activity can become an additional lucrative job [7]. In 2016 the agritourism services were rendered by 8200 service providers [13,14].

Agritourism in the rural areas can also ensure additional jobs for the rural residents as, frequently, its substantially generates the development of tourism-related sectors, especially services, commerce, food serving, processing and the automotive sectors as well as traditional handicrafts, etc. [13]. The development of the agritourism services and, as a result, an increase in the income of the rural population can enhance the financial standing of the communes. With higher revenues, the local authorities can allocate more funds to the construction of roads, waterworks and sewage systems, telecommunications services as well as to other infrastructure facilities. An enhanced infrastructure as well as an increased demand in the rural areas stimulate a development of various forms of small-and medium-sized entrepreneurship [7].

In addition. the region's culture benefits from the development of agritourism. The key benefits are definitely a change in the approach of the rural residents to ecology, their greater eco-sensitivity and a greater attentiveness to the natural environment and nature protection [15]. The residents of the rural areas start understanding that a well-preserved natural environment affects the region's attractiveness and so it starts to be considered as a source of income [16]. Such perception of nature triggers environmentally-friendly behaviors and investing in nature protection as well as popularizes the use of environmentally-friendly technologies. The development of agritourism also facilitates the protection and renovation of cultural historic sites and other forms of cultural heritage as well as creating a positive climate for maintaining the folk tradition and customs [7].

All those agritourism-development-related benefits contribute to the multifunctional rural areas' development, making the rural areas assume and commonly play non-agricultural functions, especially residential, tourist, industrial or service-providing [17]. In that way the rural areas change their image - they are no longer the areas where traditional farmers providing agricultural produce live and they are becoming an integral part of the national economy, the place with agriculture-related residents and non-agriculture-related residents [18]. An essential factor making the agritourism development more dynamic is introducing innovations to the agritourism farm offer.

Although the development of agritourism is part of the concept of sustainable rural development, as indicated above, it should be noted that its uncontrolled development can cause many potential environmental and socioeconomic threats. They may result from excessive economic activation associated with too dynamic development of mass agritourism, especially carried out in valuable natural areas $[19,20]$. In addition, it can lead to problems related to excessive infrastructure development, garbage and waste management, devastation of historically and culturally valuable objects, a decrease in the importance of local cultural values, an increase in crime and a decrease in social trust among the local community, etc. [21]. Moreover, it should also be borne in mind that the excessive development of tourism in rural areas can disrupt local social systems by exerting pressure that threatens the natural mechanisms by which these systems have been shaped and regulated [11]. In special cases, it may also lead to a reduction in agricultural production in favor of tourist activity, which in turn may lead to problems related to ensuring food security [22]. That is why an appropriate and well-thought-out strategy for the development of agritourism activities is so important, as part of local development plans, based on the principles defined by the concept of sustainable development [23].

The objective of the article is to demonstrate the study of agritourism innovativeness with a selected region in Poland as an example. In addition. the factors affecting the process of implementing 
innovations in agritourism were reviewed. An attempt has also been made to develop the conclusions on the effect of innovativeness on the development of agritourism and competitiveness of agritourism farms. To this end, the Ward method was used to perform the cluster analysis for the counties of the Podlaskie province, in Poland. As part of the primary objective the authors searched for the answers to the following questions:

- How is the term of innovation in agritourism interpreted by various authors?

- What are the examples of innovations in the development of agritourism?

- What is the spatial diversity of the counties of the Podlaskie province in terms of agritourism innovativeness?

- What is the importance of the tourist in terms of offering factors, especially innovative solutions, for the competitiveness of agritourism farms?

The respective parts of the article present the theory for innovativeness in agritourism and then the spatial analysis study part. After the introduction, in Section 2 the theoretical background is provided. This part demonstrates an in-depth review of agritourism innovativeness literature. Section 3 discusses the material and methods. Section 4 covers the cluster analysis results and presents the farm's competitive positioning index and gaining a competitive advantage on the agritourism services market. The last part of the article presents the discussion and results.

\section{Literature Review}

The term "innovativeness" comes from the Latin word innovation, meaning "introducing something new" [24]. The term was introduced to the theory of economics by Schumpeter [25] in 1912; for whom an innovative activity was a practical application and the use of novelties in the product and process (supply, manufacture and production). The key to understand the essence of innovativeness is "novelty"; innovation is all that has been used for the first time and which has generated positive economic results, and which has been usable in practice.

Innovativeness, referred to as "a beating heart of the 21st century economy" is the basic element affecting the competitiveness of respective enterprises, regions and states. Innovation is a function of creative thinking and acting, the process transforming new concepts and knowledge into new products and services [26].

Innovations appear fastest in industry and in services and in the spatial arrangement-in the most highly developed states as well as in the urban metropolises and agglomerations. In the recent years, the innovativeness of tourism operators has been attracting increasing interest of both the researchers and tourism economy practitioners [27-30]. Hjalager [31] lists five kinds of innovations in tourism (Figure 1).

In agritourism, innovations are usually introduced with a big delay. Currently, however they are considered especially important in terms of triggering a sustainable development of the rural areas. There they can involve an agricultural farm modernization and be seen in non-agricultural economy in the rural areas, especially in rural tourism and agritourism. Additionally, they create new jobs and, frequently, increase the rural residents' income and improve their quality of life [32].

The essence of innovativeness in agritourism is based on the assumption that today the tourists who decide to take a break in the rural areas search for the offer which will satisfy their expectations and, at the same time, surprise them with originality. Innovativeness in agritourism can involve both developing, from scratch, an original tourist product (e.g., a theme village using an interesting unique idea), and developing a professional marketing environment for the nature and cultural qualities found in a given area (e.g., organizing the services and tourism infrastructure around the structures of material culture and their promotion) [33].

Innovative solutions also cover the improvement and differentiation of the products already on offer, e.g., proposing a special dining offer to the tourists. Creating the original innovative tourist product is, in general, based on the use of other ideas (already existing ideas). Increasing agritourism 
farms offer innovative labeled products, e.g., using the local traditions: pottery, wickerwork, herbalism, wood sculptures, regional inns, sleeping in a barn on hay [34].

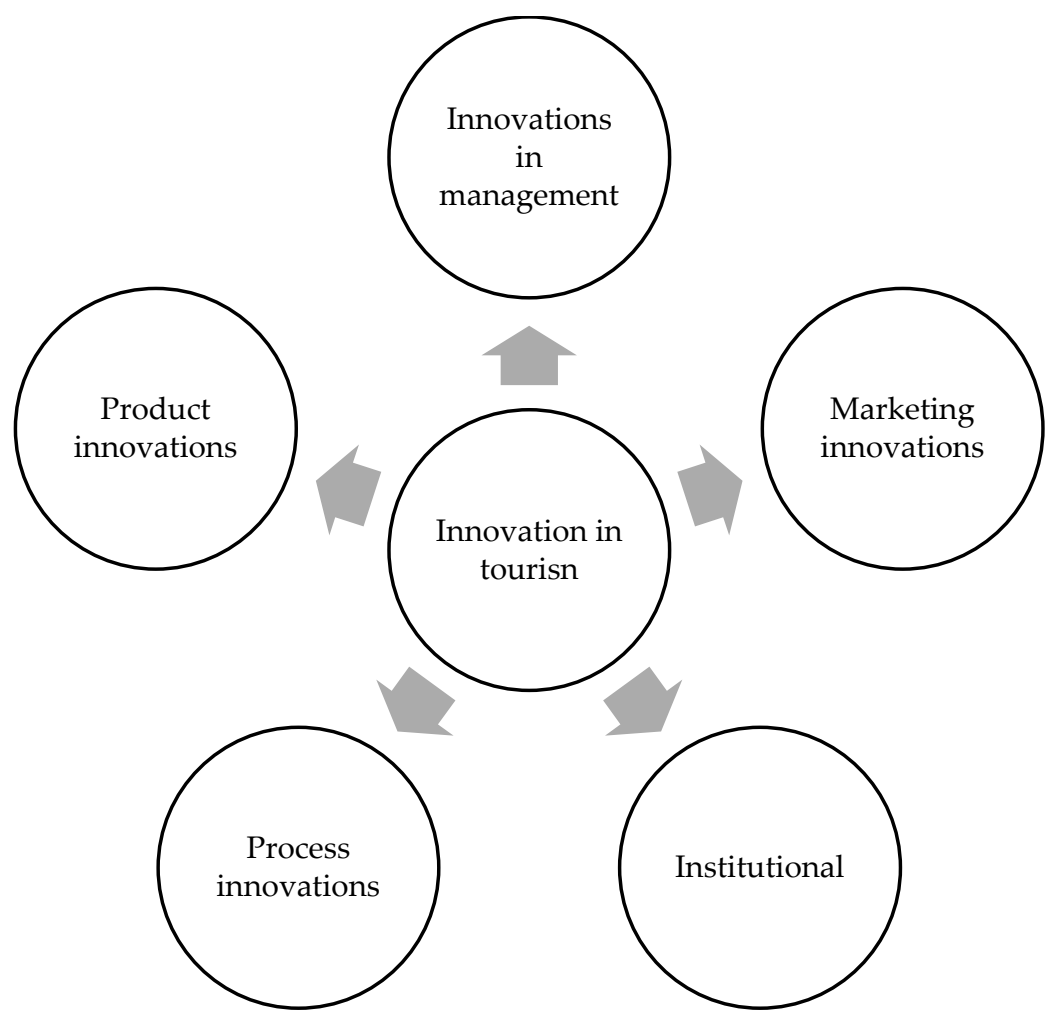

Figure 1. Innovation in tourism. Source: [31].

Innovativeness is of key importance for farm competitiveness as the facilities should keep on changing and aim at surprising the tourists with new products and proposals [35]. Agritourism should be changing continuously since stability often means stagnation and leads to a loss of competitiveness. Introducing innovative solutions facilitates the farm's remaining competitive, which then translates not only into attractiveness of a specific offer in the eyes of tourists and a good opinion, but also, tangibly, into profit [36].

The nature of innovations in agritourism to much extent depends on the demand and the creativeness of the facility owner or a local community. Table 1 presents the characteristics of the selected kinds of innovations according to the Hjalager classification [31,37].

Table 1. Features of selected types of innovations according to the Hjalager classification*.

\begin{tabular}{ccc}
\hline Types and Examples of Innovations & Features of Innovation & Innovation Management Areas \\
\hline Product & Launching new or improved products & $\begin{array}{c}\text { Production structure depends on the } \\
\text { needs of buyers, nature protection, } \\
\text { product quality }\end{array}$ \\
\hline Process & $\begin{array}{c}\text { Implementation of other production, } \\
\text { distribution, delivery, sales, etc. }\end{array}$ & $\begin{array}{c}\text { Production technologies, sales forms, } \\
\text { supply processes, financing sources }\end{array}$ \\
\hline Marketing & $\begin{array}{c}\text { Implementing new solutions to meet } \\
\text { the needs in the pursuit of profit, such } \\
\text { as prices, branding, advertising }\end{array}$ & $\begin{array}{c}\text { Marketing in terms of prices, sales, } \\
\text { distribution channels, customer } \\
\text { relationships }\end{array}$ \\
\hline Organizational & A new organization model & $\begin{array}{c}\text { Labor resources, knowledge, } \\
\text { experience, market connections }\end{array}$ \\
\hline
\end{tabular}

* Institutional innovations are not included. Source: [31,33,38]. 
In the applicable literature one can note a divergent rural-tourism and agritourism innovativeness-related terminology. Table 2 demonstrates a list of selected publications on innovations in rural tourism and agritourism.

Table 2. List of publications on innovation in rural tourism and agritourism.

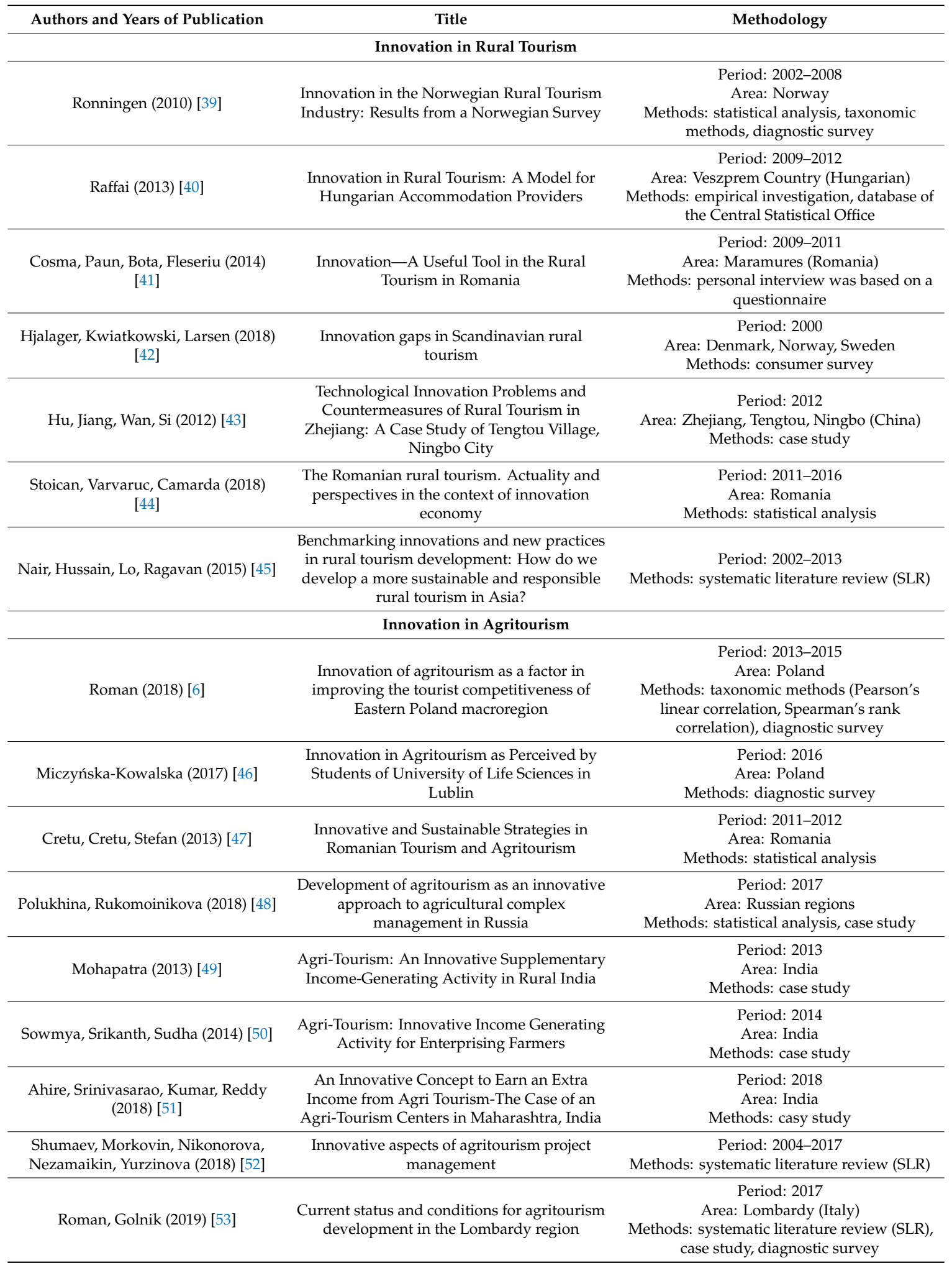

Source: [6,39-53]. 
The scientific publications presented in Table 2 show that the papers focus on the use of databases or other methods to develop the tools demonstrating a variety of innovativeness in rural tourism and agritourism. The authors use various variables to show a complexity of the problem. Some authors determine the specialization of innovativeness of rural tourism and agritourism with the comparative analysis and taxonomic methods, and some of them have conducted applicable survey studies.

Focusing on the innovativeness of rural tourism, Ronningen [39] conducted a study which involved 133 rural tourism enterprises. The study has pointed to quite a high level of innovation among the rural tourism enterprises, even if the indicators are slightly lower than the average for other tourism enterprises in Norway. The innovation capability of the rural tourism enterprises is closely related to the engagement of the enterprises in cooperation, the use of the market information systems and the actions taken to improve the employee competences. Besides, the export-oriented enterprises generate more product innovations than the other enterprises. A study conducted by Raffai [40] presents a model describing an innovation maturity of the tourist services suppliers. This author adjusted the innovation capability maturity model to identify the key five areas of capabilities essential for tourist services and classified the indicators in those areas of capabilities. Then he applied the indicators to develop a survey questionnaire for the suppliers of accommodation services in the countryside in one of the outstanding tourist destinations in Hungary-in Veszprem county. Other authors who have launched their survey study in Maramures, in Romania, were Cosma et al. [41]. In their study they have presented the essence of innovativeness of the Romanian rural tourism sector. The study analyses the product/service and marketing innovations implemented in rural tourism enterprises. Recent authors who have conducted such study are Hjalager et al. [42], presenting the potential of rural tourism in Denmark, Norway and Sweden. In their opinion, it is, however, difficult, due to innovation loopholes. The authors of the study have presented a model which identifies five Scandinavian rural tourism innovation loopholes: a portfolio loophole, a policy departments loophole, a knowledge loophole, a motivation-to-change loophole, a resources interpretation loophole. Their study demonstrates that new and potential client groups, especially from Germany, require more varied higher quality agritourism products than the present groups, e.g., in relation to the possibilities of spending time outdoors, recreational festivals and culture tutorials.

Other authors have investigated the application of the case study method and the systematic literature review (SLR). In their study Hu et al. [43] have focused on Zhejiang, Tengtou, Ningbo (China). They have noted a need of technical agritourism innovations (considering Tengtou Village as a typical case). The authors have presented three aspects of technical innovations in rural tourism, especially product management and serviced-related innovations and innovation marking. A case study was also used by Stoican, Varvaruc and Camarda [44]. The authors have made a review of the key elements of the Romanian rural tourism and an attempt at determining the rural tourism benefits in Romania. In their opinion the rural tourism in Romania is a neglected sector and the rural tourism offer should be enhanced with innovations, new tourist trends as well as future tourism valorization directions for the Romanian rural areas.

Nair et al. [45] have analyzed the contents of articles to draw conclusions from the best practices in Asia and outside it. They have also presented some innovative approaches to be adopted by Asia from non-Asian countries; New Zealand, Australia, Canada, Lesotho and Poland.

The next part of the literature review covered the innovativeness in agritourism. Just like before, it was divided into three blocks: own study, a case study and the systematic literature review (SLR).

To identify the examples of agritourism innovations, a survey study was conducted by Roman [6] and Miczyńska-Kowalska [46]. The first author conducted the survey study with 221 agritourism farm owners in Eastern Poland. He has also proposed original synthetic measures with Pearson's linear correlation and Spearman's rank correlation (the level of agritourism innovativeness development, the level of tourism competitiveness, the level of socioeconomic development), while the other author has conducted a survey study among the students of a higher education provider in Lublin to learn the opinions of the young people on the advantages of Polish agritourism and the factors driving its 
development. Other authors in their studies have applied a case study using Romania, Russia and India as examples. Cretu et al. [47] which have presented the essence of innovativeness and differences in agritourism innovativeness. In their opinion it is essential to investigate the effect of cooperation on the innovativeness and to provide a response to the question whether it enhances the innovation potential of Romania's tourist enterprises. In their study Polukhina and Rukomoinikova [48] have presented the prospects of agricultural tourism developments in Russia, focusing on the innovations in the agricultural complex, especially on the innovative approach to agritourism management. Mohapatra [49] has claimed that many of India's farmers are currently involved or are considering the use of agritourism as a method for diversifying their agricultural activity. The author has investigated the concept of agritourism, showing the key aspects of its innovative development in India. Sowmya et al. [50], on the other hand, have claimed that an essential factor of agritourism development in India and its innovative forms is showing life in the rural areas, art, culture and the cultural heritage, an exhibition of art, crafts, traditional fabrics, customs, games, agriculture and agricultural products to the potential tourists. Additional attractions on the farm can provide an example of innovative solutions, e.g., a poultry farm, a dairy farm, a goat farm, a silk processing plant.

Ahire et al. [51] have conducted a case study to focus on the scope of the operation of agritourism centers in India, especially on the current challenges and implications of sustainable development.

The last part of the literature review on the innovativeness of agritourism ends with the studies of the authors who have used the systematic literature review (SLR). Shumaev et al. [52] have presented the directions of innovative agritourism project management development. The analysis covered the international practices and experience in agritourism and its impact on the development of rural tourism in the Russian Federation. The study also covered the reality and the prospects of Russian agritourism. The study also analyzed the relationship between the traditional lifestyle in the rural areas and modern innovative technologies. Roman and Golnik [53] claim that the primary objective of implementing innovations in agritourism is a pursuit of gaining a competitive advantage on the market. Enhancing the competitiveness of agritourism enterprises depends on mutual cooperation. One can say that cooperation facilitates the development of respective entities.

To recapitulate, from the perspective of the objective of this article, the relationships between the diversity of innovativeness of rural tourism and agritourism are essential. The number of articles to cover that topic is still inconsiderable, especially the articles providing a comparative analysis of the countries in terms of agritourism innovativeness.

Table 3 presents the examples of innovation in agritourism according to the Hjalager classification [31]. For this purpose, an agritourism farm established in 1998, found in the Podlaskie province, in Poland has been selected.

Table 3. Examples of innovations in a selected agritourism farm located in the Podlaskie voivodship (in Poland) according to the Hjalager classification.

\begin{tabular}{|c|c|c|}
\hline \multicolumn{3}{|c|}{ Types and Examples of Innovations on an Agritourism Farm in Poland * } \\
\hline Product & & $\begin{array}{l}\text { Scenario games } \\
\text { Horse rally } \\
\text { Observation of the sky through a telescope, astronomical observatory } \\
\text { (gastrotourism at an agritourism farm) }\end{array}$ \\
\hline Process & 1. & Cooperation with horse riding instructors \\
\hline Marketing & 1. & Participation in the film \\
\hline Organizational & & $\begin{array}{l}\text { Using the knowledge of leaders of mountain riding tourism } \\
\text { Constant development of the offer }\end{array}$ \\
\hline
\end{tabular}

* Institutional innovations are not included. Source: own study. 
In agritourism it is hard to determine what is an innovation and what solutions constitute an imitation. Frequently, for the people running an agritourism business activity the solution introduced can be new, however, e.g., for the tourist it is no longer a novelty. Innovations in rural tourism and agritourism can be essential for developing the competitiveness of tourism enterprises and tourist areas.

Analyzing the innovativeness in agritourism, one must thus consider the market segment the tourism product is addressed to as the innovativeness expectations in the agritourism offer differ depending on the target group. Innovation is expected by business tourists who wish for modern and attractive services rendered in the rural environment [54], for example. Those who are most against innovations are the foreign guests and weekend-break tourists who, when facing a modernized agritourism offer, can consider the product of a given farm as unsatisfying their needs and will leave unsatisfied with the service not to come back to that place again [55].

Another essential agritourism-innovativeness-related aspect is the scope of innovativeness. As for such services, the level of the changes introduced should be, to some extent, limited not to disturb the core of the product when enhancing its attractiveness [55]. As stressed by Pałka [55], "implementing selected innovations can lower the rusticity provided in the offer, which, as a result, makes some customers give up purchasing the services. As a result, it can pose a threat to the economic foundations of the agritourism farm operation".

The study conducted by Roman [6] in 2013-2015 shows that innovations in agritourism are introduced by the service providers or other entities (e.g., the local community, commune authorities' clerks, agricultural consulting centers, local action groups, agritourism associations). Figure 2 presents the entities introducing innovations in rural tourism and in agritourism, and in Figure 3-their classification. The information presented in Figures 2 and 3 comes from the research of Roman [6].

Innovations in rural tourism can have an immediate effect on the development of tourism at the local scale they are introduced in (e.g., innovative theme villages, tourist trails, educational paths). Their nature depends to a great extent, on the tourist's demand and on the creativeness of a facility's owner or on the local community.

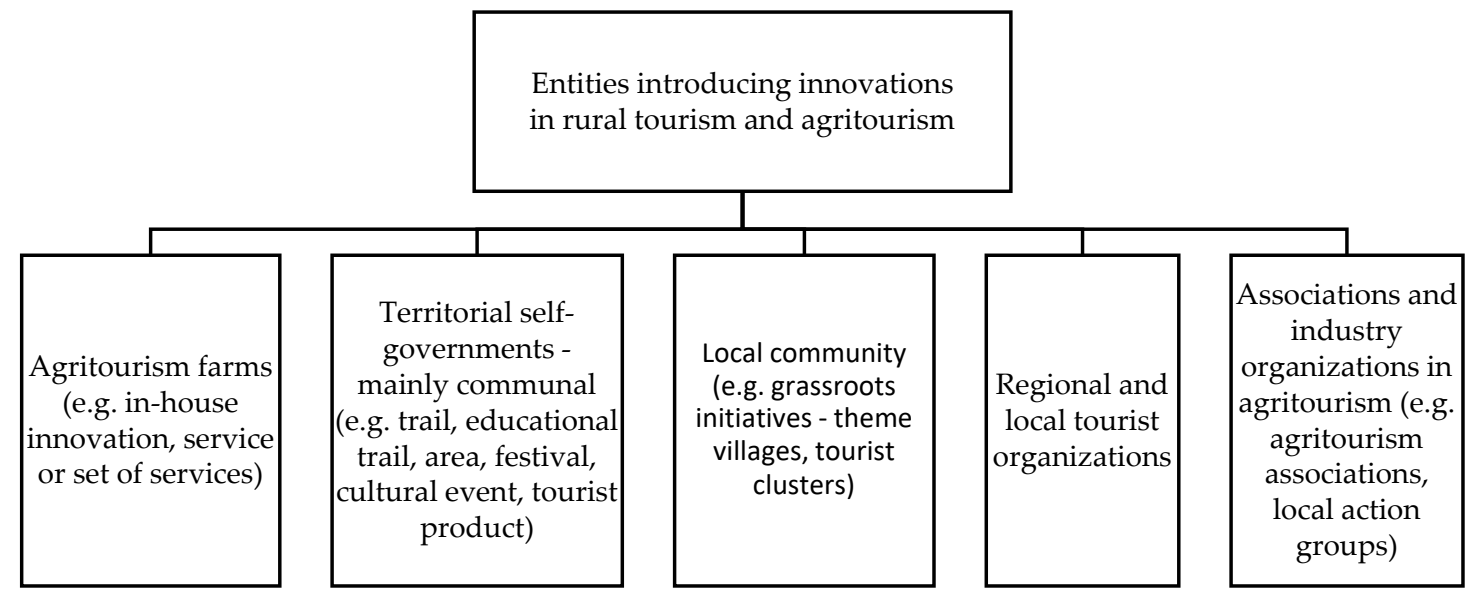

Figure 2. Groups introducing innovations in rural tourism and agritourism. Source: [6]. 


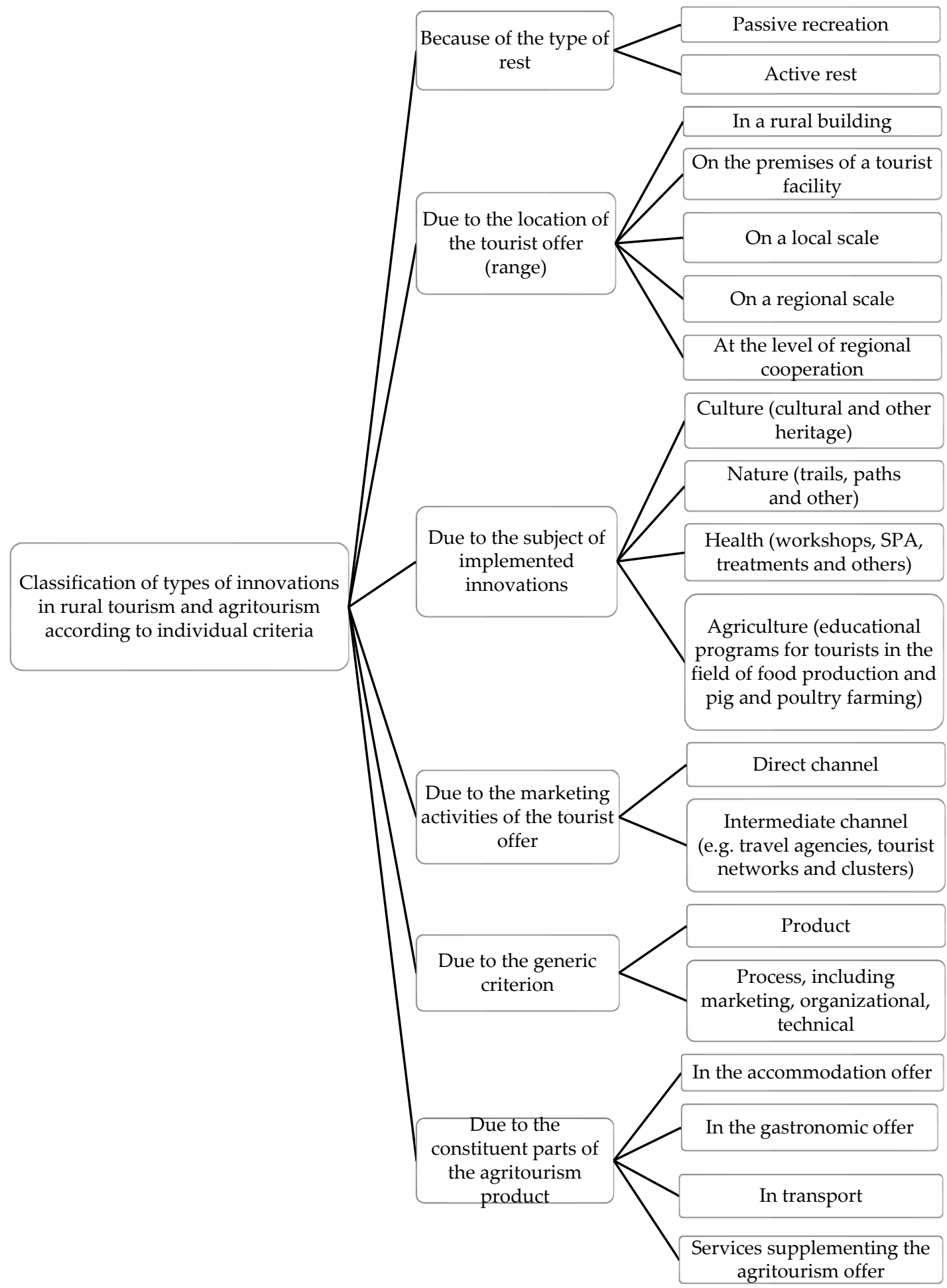

Figure 3. Classification of types of innovations in rural tourism and agritourism according to individual division criteria. Source: [6].

\section{Materials and Methods}

To present the variation in the level of agritourism innovativeness, a study was conducted in 2018 as a diagnostic survey, applying a survey questionnaire. The survey questionnaire was sent to all the agritourism service providers in the rural communes of the Podlaskie province (590 farms). Finally, the study involved 81 farmers (from 13 areas-counties) running agritourism services. 
The spatial diversity of innovations in agritourism was verified based on the analysis of clusters with the use of Ward's method. It is one of the agglomerative hierarchical clustering methods and is based on the classical criterion of the sum of squares [56]. The division should be carried out in such a way that objects of one group (class) are as similar as possible and those of different classes as different as possible. The measures of similarities or differences are based on the distance between the units [57]. To choose the number of classes, cubic clustering criterion (CCC) [58] and Pseudo F [59] were used. A detailed procedure for getting the best results can be found in Roman et al. [60]. All the calculations were made with the use of SAS 9.4 software [61].

In order to verify the spatial diversity of agritourism, the authors based the analysis on primary data (surveys) and public data from the Central Statistical Office in Poland [62].

Thirteen variables were chosen to analyze the spatial diversity of innovations in agritourism in the Podlaskie voivodeship. These variables are as follows:

$\mathrm{x}_{1}$ Inputs allocated to innovations by the agritourism farm owners in the county;

$\mathrm{x}_{2}$ analysis of the actions of competitors (tourism market observation) made by the agritourism farm owners in the county;

$\mathrm{x}_{3}$ scale of investing in the innovative activity over the last three years on agritourism farms in the county;

$\mathrm{x}_{4}$ scale of the innovative products sold in the total number of the agritourism farms studied in the county;

$\mathrm{x}_{5}$ level of education of the rural service providers in the county;

$\mathrm{x}_{6}$ level of the foreign language competence declared by the service providers in the total number of the agritourism farms studied in the county;

$\mathrm{x}_{7} \quad$ willingness of the service providers to develop their professional qualifications in the county;

$\mathrm{x}_{8}$ participation of the service providers in innovativeness trainings and courses in the total number of the agritourism farms studied in the county;

$\mathrm{x}_{9}$ level of establishing cooperation with other entities in terms of execution of innovative projects in the total number of the agritourism farms studied in the county;

$\mathrm{x}_{10}$ level of taking promotional actions by the agritourism farms in the county;

$\mathrm{x}_{11}$ scope of the agritourism offer (the total number of attractions offered by the facility owner) in the total number of the agritourism farms studied in the county;

$\mathrm{x}_{12}$ transport infrastructure and availability in the counties studied;

$\mathrm{x}_{13}$ effect of innovations on the number of visiting tourists in the total number of agritourism farms studied in the county.

All the variables could assume the value from 1 to 5 , where 1 means a very low level, and 5-very high level of the value of a given variable. The data for variable $X_{12}$ comes from the database of the central statistics authority (GUS) in Poland, and the other variables-from the survey study conducted.

The descriptive statistics of variables can be found in Table 4 .

The variables were selected on purpose so that it is possible to research of the innovation in agritourism. It should be mentioned that, apart from the substantive criterion, the choice of the variables also resulted from the low mutual correlation of variables (correlation rate below 0.8) (Table 5). 
Table 4. Descriptive statistics of variables.

\begin{tabular}{ccccccc}
\hline & Mean & Median & Minimum & Maximum & $\begin{array}{c}\text { Standard } \\
\text { Deviation }\end{array}$ & $\begin{array}{c}\text { Coefficient of } \\
\text { Variation (CV) }\end{array}$ \\
\hline $\mathrm{X}_{1}$ & 3.50 & 3.55 & 1.33 & 5.00 & 0.99 & $28 \%$ \\
$\mathrm{X}_{2}$ & 2.42 & 2.55 & 1.00 & 3.50 & 0.80 & $33 \%$ \\
$\mathrm{X}_{3}$ & 2.87 & 3.08 & 2.00 & 4.00 & 0.68 & $23 \%$ \\
$\mathrm{X}_{4}$ & 1.61 & 1.80 & 1.00 & 2.67 & 0.73 & $45 \%$ \\
$\mathrm{X}_{5}$ & 3.45 & 3.17 & 2.00 & 5.00 & 0.89 & $26 \%$ \\
$\mathrm{X}_{6}$ & 3.08 & 3.00 & 2.00 & 4.00 & 0.59 & $19 \%$ \\
$\mathrm{X}_{7}$ & 2.66 & 3.00 & 1.50 & 3.70 & 0.61 & $23 \%$ \\
$\mathrm{X}_{8}$ & 4.60 & 4.50 & 4.20 & 5.00 & 0.29 & $6 \%$ \\
$\mathrm{X}_{9}$ & 2.44 & 2.27 & 1.33 & 4.50 & 0.83 & $34 \%$ \\
$\mathrm{X}_{10}$ & 3.52 & 3.50 & 1.67 & 5.00 & 0.93 & $27 \%$ \\
$\mathrm{X}_{11}$ & 3.40 & 3.50 & 1.33 & 5.00 & 0.99 & $29 \%$ \\
$\mathrm{X}_{12}$ & 2.97 & 3.25 & 1.33 & 4.00 & 0.82 & $28 \%$ \\
$\mathrm{X}_{13}$ & 3.47 & 3.30 & 3.00 & 4.00 & 0.40 & $12 \%$ \\
\hline
\end{tabular}

Where: $x_{1}$-Inputs allocated to innovations by the agritourism farm owners in the county; $x_{2}$-analysis of the actions of competitors (tourism market observation) made by the agritourism farm owners in the county; $x_{3}$-scale of investing in the innovative activity over the last three years on agritourism farms in the county; $x_{4}$-scale of the innovative products sold in the total number of the agritourism farms studied in the county; $x_{5}$-level of education of the rural service providers in the county; $x_{6}$-level of the foreign language competence declared by the service providers in the total number of the agritourism farms studied in the county; $x_{7}$-willingness of the service providers to develop their professional qualifications in the county; $x_{8}$-participation of the service providers in innovativeness trainings and courses in the total number of the agritourism farms studied in the county; $\mathrm{x}_{9}$-level of establishing cooperation with other entities in terms of execution of innovative projects in the total number of the agritourism farms studied in the county; $\mathrm{x}_{10}$-level of taking promotional actions by the agritourism farms in the county; $x_{11}$-scope of the agritourism offer (the total number of attractions offered by the facility owner) in the total number of the agritourism farms studied in the county; $\mathrm{x}_{12}$ - transport infrastructure and availability in the counties studied; $\mathrm{x}_{13}$ - effect of innovations on the number of visiting tourists in the total number of agritourism farms studied in the county.

Table 5. Pearson's correlation indicators.

\begin{tabular}{|c|c|c|c|c|c|c|c|c|c|c|c|c|c|}
\hline & $X_{1}$ & $X_{2}$ & $X_{3}$ & $\mathrm{X}_{4}$ & $X_{5}$ & $X_{6}$ & $X_{7}$ & $\mathrm{X}_{8}$ & $X_{9}$ & $X_{10}$ & $X_{11}$ & $X_{12}$ & $X_{13}$ \\
\hline$X_{1}$ & 1.00 & & & & & & & & & & & & \\
\hline$x_{2}$ & 0.50 & 1.00 & & & & & & & & & & & \\
\hline$x_{3}$ & -0.40 & -0.49 & 1.00 & & & & & & & & & & \\
\hline$X_{4}$ & 0.44 & 0.08 & 0.41 & 1.00 & & & & & & & & & \\
\hline$X_{5}$ & 0.75 & 0.57 & -0.27 & 0.41 & 1.00 & & & & & & & & \\
\hline$x_{6}$ & 0.16 & 0.13 & -0.37 & -0.42 & -0.13 & 1.00 & & & & & & & \\
\hline$x_{7}$ & 0.46 & 0.73 & 0.01 & 0.40 & 0.74 & -0.08 & 1.00 & & & & & & \\
\hline$X_{8}$ & 0.52 & -0.08 & -0.41 & 0.03 & 0.23 & 0.22 & -0.35 & 1.00 & & & & & \\
\hline$X_{9}$ & 0.63 & 0.62 & -0.52 & -0.14 & 0.58 & 0.47 & 0.57 & 0.08 & 1.00 & & & & \\
\hline$x_{10}$ & 0.69 & 0.80 & -0.67 & 0.11 & 0.67 & 0.25 & 0.51 & 0.39 & 0.51 & 1.00 & & & \\
\hline$x_{11}$ & 0.78 & 0.53 & -0.24 & 0.46 & 0.64 & 0.10 & 0.63 & 0.02 & 0.75 & 0.42 & 1.00 & & \\
\hline$X_{12}$ & 0.62 & 0.80 & -0.62 & 0.20 & 0.64 & 0.22 & 0.67 & 0.05 & 0.63 & 0.79 & 0.61 & 1.00 & \\
\hline$x_{13}$ & 0.32 & 0.33 & 0.05 & 0.28 & 0.77 & -0.37 & 0.55 & 0.11 & 0.26 & 0.31 & 0.22 & 0.16 & 1.00 \\
\hline
\end{tabular}

Where: $x_{1}$-Inputs allocated to innovations by the agritourism farm owners in the county; $x_{2}$-analysis of the actions of competitors (tourism market observation) made by the agritourism farm owners in the county; $\mathrm{x}_{3}$ - scale of investing in the innovative activity over the last three years on agritourism farms in the county; $\mathrm{x}_{4}$ - scale of the innovative products sold in the total number of the agritourism farms studied in the county; $x_{5}$-level of education of the rural service providers in the county; $x_{6}$-level of the foreign language competence declared by the service providers in the total number of the agritourism farms studied in the county; $x_{7}$-willingness of the service providers to develop their professional qualifications in the county; $\mathrm{x}_{8}$-participation of the service providers in innovativeness trainings and courses in the total number of the agritourism farms studied in the county; $x_{9}$-level of establishing cooperation with other entities in terms of execution of innovative projects in the total number of the agritourism farms studied in the county; $\mathrm{x}_{10}$-level of taking promotional actions by the agritourism farms in the county; $\mathrm{x}_{11}$ - scope of the agritourism offer (the total number of attractions offered by the facility owner) in the total number of the agritourism farms studied in the county; $\mathrm{x}_{12}$-transport infrastructure and availability in the counties studied; $\mathrm{x}_{13}$ - effect of innovations on the number of visiting tourists in the total number of agritourism farms studied in the county. 


\section{Results of the Cluster Analysis and Proposed Proprietary Index of Farm Competitiveness}

\subsection{Spatial Diversity of Agritourism Innovativeness in Poviats}

The study shows a considerable variation in the counties of the Podlaskie province in terms of the agritourism innovativeness level (low, medium and high agritourism innovativeness levels). Figure 4 presents the results of grouping of the counties in terms of the level of innovativeness. One can observe the biggest clusters of developed counties in the northeastern and central part of the Podlaskie province (Cluster 1), which are attractive in terms of agritourism innovativeness: the Suwalski, Sejneński, Augustowski, Sokólski, Białostocki and Hajnowski counties. In those counties the average value of most of the variables was highest, as compared with the other two clusters. In that cluster there was noted a lower average level in terms of the service providers' education background and foreign language competence as well as the impact of innovations on the number of visiting tourists (Table 6).

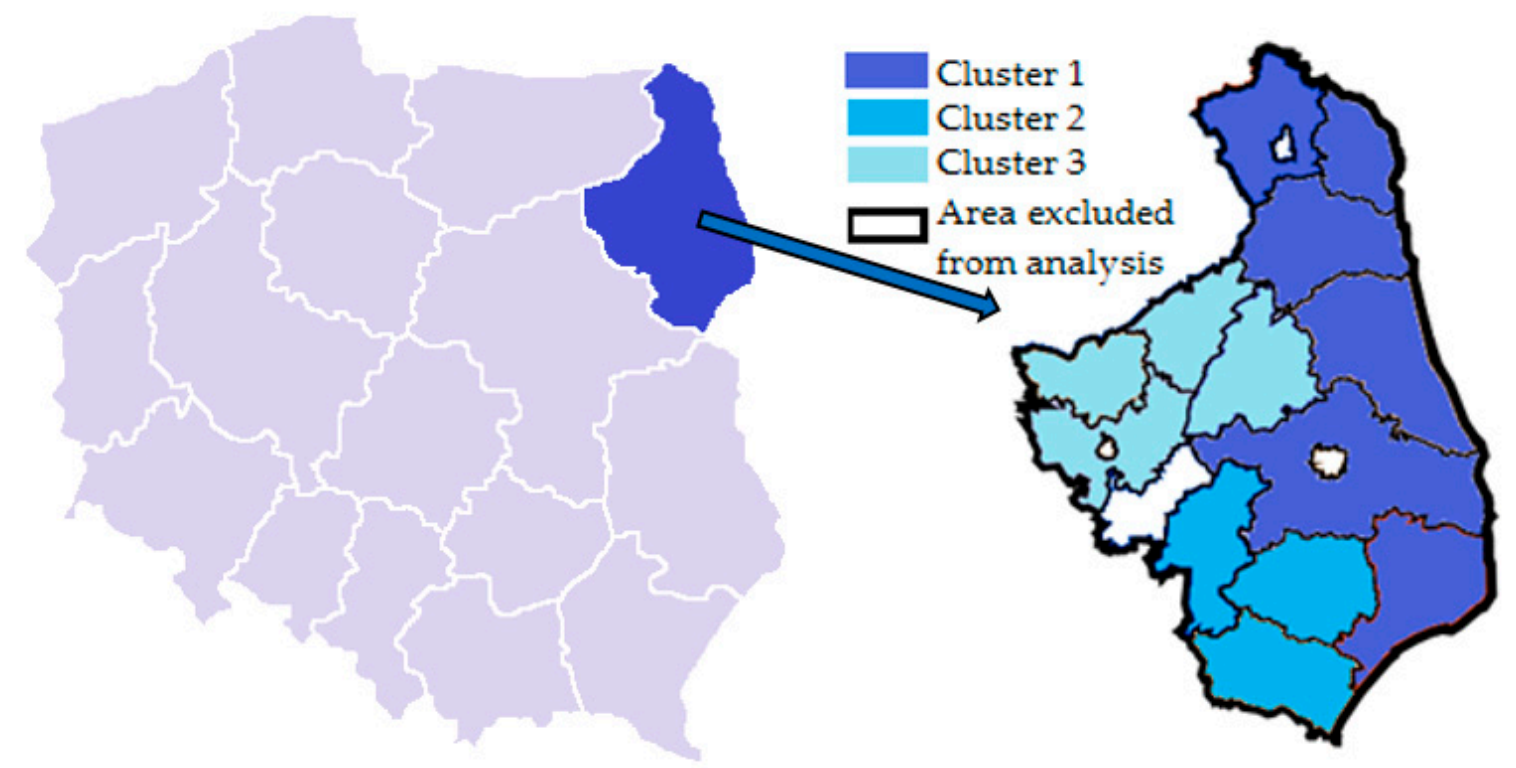

Figure 4. Grouping of poviats according to cluster analysis. Source: Own research.

The areas of Cluster 1 show a high forest cover percentage and favorable natural and cultural conditions; Suwalszczyzna, Sejneńszczyzna, Augustowszczyzna, Białostocczyzna and the Hajnowski county. The areas show a very high number of agritourism farms, which is due to the nature qualities, especially lakes, rivers, post-glacial forms and abundant fauna and flora. The areas are protected in numerous national and landscape parks; the Wigierski National Park, the Biebrzański National Park, the Narwiański National Park, the Białowieski National Park, the Mazurski Landscape Park, the Landscape Park of Knyszyńska Forest, the Narwiański Landscape Park and the Suwalski Landscape Park. The areas can be considered one of the cleanest and healthiest due to the peripheral location and large distances from the urbanized areas ("Green Lungs of Poland"). Interestingly, in those areas there are two health resorts of the Podlaskie province; Augustów and Supraśl. The tourist base of those areas is very well-developed (numerous hotels, guest houses, agritourism farms).

Cluster 2 included three neighboring counties. According to the analysis, those were the counties with an average level of agritourism innovativeness. In those counties the service provides showed the greatest education background, foreign language competence and training and course participation. The tourist offers of the agritourism farms located in those counties was most abundant in terms of the number of attractions, which can point to a low specialization of the farms, related to their much lower number in those areas. 
Table 6. Clusters descriptive characteristics.

\begin{tabular}{|c|c|c|c|c|c|c|c|c|c|c|c|c|c|}
\hline & & $\mathrm{C} 1$ & $\mathrm{C} 2$ & $\mathrm{C} 3$ & $\mathrm{C} 1$ & $\mathrm{C} 2$ & $\mathrm{C} 3$ & $\mathrm{C} 1$ & $\mathrm{C} 2$ & $\mathrm{C} 3$ & C1 & $\mathrm{C} 2$ & $\mathrm{C} 3$ \\
\hline \multirow{14}{*}{$\begin{array}{l}\text { Ward's } \\
\text { method }\end{array}$} & & \multicolumn{3}{|c|}{ Mean } & \multicolumn{3}{|c|}{ Minimum } & \multicolumn{3}{|c|}{ Maximum } & \multicolumn{3}{|c|}{ Coefficient of Variation (CV) } \\
\hline & $\mathrm{X}_{1}$ & 4.3 & 3.3 & 3.2 & 4.0 & 2.7 & 1.3 & 5.0 & 4.1 & 5.0 & $15 \%$ & $11 \%$ & $44 \%$ \\
\hline & $X_{2}$ & 2.6 & 2.2 & 2.4 & 2.2 & 1.0 & 1.0 & 3.5 & 3.0 & 3.0 & $17 \%$ & $54 \%$ & $35 \%$ \\
\hline & $x_{3}$ & 3.0 & 2.9 & 2.5 & 2.6 & 2.0 & 2.0 & 3.4 & 3.5 & 4.0 & $9 \%$ & $28 \%$ & $32 \%$ \\
\hline & $\mathrm{X}_{4}$ & 1.8 & 1.5 & 1.4 & 1.2 & 1.0 & 1.0 & 2.3 & 2.0 & 2.7 & $22 \%$ & $47 \%$ & $71 \%$ \\
\hline & $X_{5}$ & 3.2 & 3.8 & 3.5 & 2.6 & 2.5 & 2.0 & 4.0 & 5.0 & 5.0 & $15 \%$ & $27 \%$ & $32 \%$ \\
\hline & $x_{6}$ & 3.1 & 3.3 & 2.8 & 2.4 & 3.0 & 2.0 & 3.9 & 3.5 & 4.0 & $17 \%$ & $7 \%$ & $27 \%$ \\
\hline & $X_{7}$ & 2.9 & 2.5 & 2.5 & 2.4 & 1.5 & 1.5 & 3.7 & 3.0 & 3.0 & $16 \%$ & $28 \%$ & $25 \%$ \\
\hline & $\mathrm{X}_{8}$ & 4.4 & 4.8 & 4.8 & 4.2 & 4.5 & 4.3 & 4.5 & 5.0 & 5.0 & $3 \%$ & $5 \%$ & $6 \%$ \\
\hline & $X_{9}$ & 2.3 & 3.2 & 2.1 & 1.7 & 2.0 & 1.3 & 3.5 & 4.5 & 3.0 & $26 \%$ & $32 \%$ & $29 \%$ \\
\hline & $X_{10}$ & 4.8 & 3.2 & 2.8 & 4.5 & 2.8 & 1.3 & 5.0 & 4.8 & 5.0 & $15 \%$ & $5 \%$ & $49 \%$ \\
\hline & $X_{11}$ & 3.5 & 4.2 & 2.7 & 2.8 & 3.5 & 1.3 & 4.2 & 5.0 & 4.0 & $12 \%$ & $15 \%$ & $48 \%$ \\
\hline & $X_{12}$ & 3.2 & 3.0 & 2.5 & 2.8 & 1.5 & 1.3 & 3.6 & 4.0 & 4.0 & $9 \%$ & $36 \%$ & $37 \%$ \\
\hline & $X_{13}$ & 3.3 & 3.5 & 3.8 & 3.0 & 3.0 & 3.0 & 3.7 & 4.0 & 4.0 & $7 \%$ & $12 \%$ & $12 \%$ \\
\hline
\end{tabular}

Where: $\mathrm{C} 1$-cluster $1 ; \mathrm{C} 2$-cluster 2; $\mathrm{C} 3$-cluster 3; $\mathrm{x}_{1}$-Inputs allocated to innovations by the agritourism farm owners in the county; $\mathrm{x}_{2}$-analysis of the actions of competitors (tourism market observation) made by the agritourism farm owners in the county; $x_{3}$ - scale of investing in the innovative activity over the last three years on agritourism farms in the county; $x_{4}$ - scale of the innovative products sold in the total number of the agritourism farms studied in the county; $x_{5}$-level of education of the rural service providers in the county; $x_{6}$-level of the foreign language competence declared by the service providers in the total number of the agritourism farms studied in the county; $x_{7}$-willingness of the service providers to develop their professional qualifications in the county; $\mathrm{x}_{8}$ - participation of the service providers in innovativeness trainings and courses in the total number of the agritourism farms studied in the county; $x_{9}$-level of establishing cooperation with other entities in terms of execution of innovative projects in the total number of the agritourism farms studied in the county; $\mathrm{x}_{10}$-level of taking promotional actions by the agritourism farms in the county; $\mathrm{x}_{11}$-scope of the agritourism offer (the total number of attractions offered by the facility owner) in the total number of the agritourism farms studied in the county; $x_{12}$-transport infrastructure and availability in the counties studied; $x_{13}$-effect of innovations on the number of visiting tourists in the total number of agritourism farms studied in the county.

Cluster 3 provided the other counties, representing a low level of innovativeness. For eight variables the agritourism farms in those counties recorded the lowest average values. Despite numerous trainings and courses taken by the service providers, the level of inputs and the investment scale were lowest. On those farms the service providers noted, however, a high impact of innovation on the number of tourists visiting a given facility. However, interestingly, the farms in those counties mostly focused on agricultural activities, especially dairy production and not the agritourism activities.

Very important for the development of agritourism in terms of innovativeness is the region, the location of the agritourism farms, the tourism potential, especially the nature qualities. According to the authors, the areas of Cluster 1 provide the conditions favorable to the development of agritourism; the areas with a high tourism potential. In this area the agritourism activity has been developing and innovative actions are needed.

\subsection{Farm's Competitive Positioning Index and Gaining an Advantage on the Agritourism Services Market, Considering the Innovations Introduced}

The agritourism farms operated by the service providers can increase their competitive positioning on the tourist services market. This can include the agritourism facilities found in an attractive location as well as the farms whose location is not satisfactory and whose offer is poor, with no innovations introduced. For this purpose, an original index was developed based on the survey study. It includes the internal and external factors which affect the development of the competitive positioning of the farm and how to get an advantage in the agritourism services market. Tables 7 and 8 present the internal and external factors of the agritourism farm affecting the development of its competitive positioning and which can lead to a gain in the competitive advantage in the agritourism services market. The index can be useful to the service providers to evaluate the positioning of the farm and to gain a competitive advantage in the agritourism services market (and that is why it was constructed). 
Table 7. Assessment of internal factors of an agritourism farm which has an impact on building its competitive position and gaining an advantage in the agritourism services market.

\begin{tabular}{|c|c|c|c|}
\hline Specification & \multicolumn{2}{|c|}{ Characteristic } & Points \\
\hline \multirow{8}{*}{ Accommodation base } & \multirow{2}{*}{ Residential building } & $\begin{array}{l}\text { Beds in a building other than the } \\
\text { owner's }\end{array}$ & 4 \\
\hline & & $\begin{array}{l}\text { Bed places in the same house as the } \\
\text { owner }\end{array}$ & 1 \\
\hline & \multirow{6}{*}{ Number of rooms } & Number of rooms is over 50 & 6 \\
\hline & & Number of rooms from 40 to 50 & 5 \\
\hline & & Number of rooms from 30 to 40 & 4 \\
\hline & & Number of rooms from 20 to 30 & 3 \\
\hline & & Number of rooms from 10 to 20 & 2 \\
\hline & & Number of rooms up to 10 & 1 \\
\hline \multirow{5}{*}{ Catering base } & \multicolumn{2}{|c|}{$\begin{array}{l}\text { Offering full board (breakfast, lunch, dinner), also from our own organic } \\
\text { products (e.g., vegetables, fruit, cheese, honey, eggs, etc.) }\end{array}$} & 4 \\
\hline & \multicolumn{2}{|c|}{ Offering breakfast and dinner } & 3 \\
\hline & \multicolumn{2}{|c|}{$\begin{array}{l}\text { The owner offers only breakfast and in addition a kitchenette is available } \\
\text { to guests }\end{array}$} & 2 \\
\hline & \multicolumn{2}{|c|}{ The owner does not offer catering and a kitchenette is available } & 1 \\
\hline & \multicolumn{2}{|c|}{ The owner does not offer the sale of meals and there is no kitchenette } & 0 \\
\hline \multirow{9}{*}{$\begin{array}{l}\text { Tourist offer of an } \\
\text { agritourism farm }\end{array}$} & Reactive & Only accommodation and meals & 0 \\
\hline & \multirow{8}{*}{ Active } & Horse riding & 1 \\
\hline & & Workshops & 1 \\
\hline & & $\begin{array}{l}\text { Educational shows for children and } \\
\text { adolescents }\end{array}$ & 1 \\
\hline & & Fishing & 1 \\
\hline & & Mushrooming & 1 \\
\hline & & Guided tours of the area & 1 \\
\hline & & $\begin{array}{l}\text { Organizing events (e.g., baptisms, } \\
\text { communions, etc.) }\end{array}$ & 1 \\
\hline & & Swimming pool & 1 \\
\hline \multirow{9}{*}{$\begin{array}{l}\text { Facilities for tourists as } \\
\text { part of the tourist offer }\end{array}$} & \multirow{5}{*}{ Additional farm traction } & Place for a bonfire/grill & 1 \\
\hline & & Garden/orchard (or show garden) & 1 \\
\hline & & Play area for children & 1 \\
\hline & & Gaming field & 1 \\
\hline & & Parking on the property & 1 \\
\hline & \multirow{4}{*}{$\begin{array}{l}\text { Sports or recreation } \\
\text { equipment }\end{array}$} & Sunbeds & 1 \\
\hline & & Bikes & 1 \\
\hline & & Canoes, a boat or paddle boat & 1 \\
\hline & & Nordic walking & 1 \\
\hline \multirow{3}{*}{$\begin{array}{l}\text { Introduced innovations or } \\
\quad \text { imitations }\end{array}$} & \multicolumn{2}{|c|}{ I introduce my own (original) innovative ideas on the farm } & 3 \\
\hline & \multicolumn{2}{|c|}{ I introduce ideas imitating other owners from Poland or abroad } & 1 \\
\hline & \multicolumn{2}{|c|}{ I do not introduce innovations or imitations on an agritourism farm } & 0 \\
\hline
\end{tabular}


Table 8. Assessment of external factors of an agritourism farm having an impact on building its competitive position and gaining an advantage in the agritourism services market.

\begin{tabular}{|c|c|c|c|}
\hline Specification & Char & Icteristic & Points \\
\hline \multirow{13}{*}{$\begin{array}{l}\text { Tourist potential } \\
\text { of rural areas }\end{array}$} & \multirow{6}{*}{$\begin{array}{l}\text { Woodiness of the area } \\
\text { (occurrence of forests) }\end{array}$} & $\begin{array}{l}\text { In the vicinity of an agritourism } \\
\text { farm up to } 500 \mathrm{~m}\end{array}$ & 5 \\
\hline & & From $500 \mathrm{~m}$ to $2 \mathrm{~km}$ & 4 \\
\hline & & From $2 \mathrm{~km}$ to $5 \mathrm{~km}$ & 3 \\
\hline & & From $5 \mathrm{~km}$ to $10 \mathrm{~km}$ & 2 \\
\hline & & Above $10 \mathrm{~km}$ & 1 \\
\hline & & $\begin{array}{l}\text { There are no forests in the area up to } \\
10 \mathrm{~km} \text { from the agritourism farm }\end{array}$ & 0 \\
\hline & \multirow{4}{*}{$\begin{array}{l}\text { Water reservoirs (sea, lake, river, } \\
\text { lagoon) }\end{array}$} & From 500 to $2 \mathrm{~km}$ & 6 \\
\hline & & From $2 \mathrm{~km}$ to $5 \mathrm{~km}$ & 5 \\
\hline & & From $5 \mathrm{~km}$ to $10 \mathrm{~km}$ & 3 \\
\hline & & Above $10 \mathrm{~km}$ & 2 \\
\hline & $\begin{array}{l}\text { Mountains (mountain peaks, } \\
\text { mountain ranges) }\end{array}$ & $\begin{array}{l}\text { Mountain trail (up to } 10 \mathrm{~km} \text { from } \\
\text { the farm) }\end{array}$ & 5 \\
\hline & $\begin{array}{l}\text { Tourist routes (e.g., walking, } \\
\text { cycling, canoeing, riding, skiing, } \\
\text { nature, history) }\end{array}$ & $\begin{array}{l}\text { Up to } 20 \mathrm{~km} \text { from the agritourism } \\
\text { farm }\end{array}$ & 5 \\
\hline & Educational (didactic) paths & $\begin{array}{l}\text { Occurrence of the path (up to } 10 \mathrm{~km} \\
\text { from the agritourism farm) }\end{array}$ & 3 \\
\hline Location of the object & \multicolumn{2}{|c|}{$\begin{array}{l}\text { The facility is located over } 60 \mathrm{~km} \text { from a large urban agglomeration (a } \\
\text { city of over } 100,000 \text { inhabitants or larger) }\end{array}$} & 5 \\
\hline $\begin{array}{l}\text { Competition on the } \\
\text { agritourism market }\end{array}$ & \multicolumn{2}{|c|}{ No competition and the nearest agritourism farm is located up to $10 \mathrm{~km}$} & 10 \\
\hline \multirow[t]{2}{*}{ Social capital } & \multicolumn{2}{|c|}{$\begin{array}{l}\text { Starts cooperation with other entities (e.g., commune office, marshal } \\
\text { office, local action groups, local and regional tourist organizations, } \\
\text { agritourism associations, tourist clusters, theme villages) }\end{array}$} & 3 \\
\hline & \multicolumn{2}{|c|}{ I do not cooperate with other entities } & 0 \\
\hline
\end{tabular}

The internal and external factors show that a given farm can be allocated a specific score according to various categories (the maximum total score is 75). The score must be counted and a specific positioning in the agritourism services market must be attributed:

- A very highly competitive positioning of an agritourism farm (the score above 50);

- A highly competitive positioning of the agritourism farm (the score from 40 to 50);

- An average competitive positioning of the agritourism farm (the score from 30 to 40);

- A low competitive positioning of the agritourism farm (the score from 20 to 30);

- A very low competitive positioning of the agritourism farm (the score below 20).

If the agritourism farm meets the specific criteria, it is more competitive than the other facility. In that way it is also possible to compare whether further actions are required, e.g., a greater farm promotion, introducing innovations or applying for the facility category to be awarded to make the offer more available on the market. The authors of the article are aware that not all the elements of the attractiveness of the farm and its vicinity are considered in the index. The index is innovative and such a concept is missing in the applicable rural tourism and agritourism literature.

The article provides a ranking of agritourism farms based on the index of competitive positioning of the farm and gaining a competitive advantage in the agritourism services market. For this purpose, three agritourism farms found in the following countries were selected: 
- Poland (Podlaskie province, Sokólski county, Suchowola commune);

- Germany (Oberbayern; Südostoberbayern region, Rosenheim county);

- France (Var department, Provence region).

The following countries were selected in the ranking in a targeted manner, however, agritourism farms were selected at random. Their tourist offer was placed on the websites of the facilities. A detailed ranking of the three selected agritourism farms is presented in Table 9.

Table 9. Ranking of selected agritourism farms using the farm's competitive position indicator and gaining an advantage on the agritourism services market.

\begin{tabular}{ccc}
\hline Specification & Points Obtained & Position on the Agritourism Market \\
\hline $\begin{array}{c}\text { Agritourism farm in Poland } \\
\text { (Podlasie voivodship, Sokólski } \\
\text { poviat, Suchowola commune) }\end{array}$ & 49 & Highly competitive position \\
$\begin{array}{c}\text { An agritourism farm in Germany } \\
\text { (Upper Bavaria, Südostoberbayern } \\
\text { region, Rosenheim district) } \\
\text { Farm stay in France (Var }\end{array}$ & 58 & Very highly competitive position \\
department, Provence region) & 32 & Average competitive position \\
\hline
\end{tabular}

Source: Own study.

The top positioning in the "ranking of competitiveness" was recorded for the agritourism farm located in Germany due to a very good location of the facility (close to forests and lakes), as well as due to a lack of such farms in the vicinity. Additionally, the service providers will launch a continuous cooperation with numerous tourism entities and institutions supporting the development of agritourism in the area.

An important aspect of agritourism is enhancing the competitiveness and its dynamic development. For this purpose, the possibilities of introducing innovative processes and/or products on the market must be created. The term "innovation" in tourism and agritourism is not unambiguous or easy to define. The owners of agritourism farms should invest in lodging development and introduce innovative solutions. Innovations can be considered to be novelties, innovative changes, new inventions, utility models or technology improvement designs. It is essential to take a positive approach to the risk taken in the competitive environment. Innovations are an important factor for solving many problems and seeking development niches. They can be done individually or in groups, especially, e.g., in clusters.

Innovations in agritourism can emerge in various forms, e.g., by making the stay, weekend or trip offer more attractive. A farm stay can be organized for the disabled, those in need of health care (e.g., care farming as an example of innovation), the non-self-reliant, the elderly, for families or caretakers with small children, for those who love horse-riding, fishing and mushroom-picking, those interested in working in the field, trekking or health food.

\section{Discussion and Conclusions}

The development of agritourism services changes the image of the rural areas and increases the income of the farmer and the family [63]. It also triggers the development of related branches, related to the tourism, especially services, commerce, food serving, traditional handicrafts, etc. [2]. Agritourism triggers the initiative of the rural areas residents and encourages them to be creative $[5,12]$. An opportunity for the development of agritourism can today be offered by various innovations [26]. However, one must remember not to "lose" what is crucial, namely the essence of the rural area.

The topic of innovation in agritourism presented in the article is the ability to creatively combine resources, such as values, infrastructure, services, knowledge and cooperation skills. As already mentioned, one of the factors in creating innovation in agritourism is cooperation. Karampela et al. are of the same opinion [64]. 
It should also be noted that the assessment of the potential of agritourism in terms of innovation requires a close look at the specific features of the agritourism market that affect its nature, both on the demand and supply side. The assessment of the achievements to date related to innovative solutions in agritourism is not explicit, but to a large extent the specificity of innovation is determined by external (demand) conditions, which are essentially objective in nature and to which tourism operators should adapt. The specific features of agritourism when creating an innovative product were described in the works by Joshi and Bhujbal [65].

The concept of innovation can be interpreted and perceived differently, e.g., not every innovation can mean the same to agritourism farm owners and tourists. In addition, not every tourist product can be innovative and affect the development of the region [6]. However, innovations in agritourism are introduced from time to time, in long intervals, which is why most processes involve imitation (consisting of repeating and imitating specific activities that have already been carried out in the past). These may be elements of a tourist offer, agritourism product or agritourism facilities that were introduced into reality. Imitation in agritourism may concern the enrichment of agritourism services (accommodation, catering, transport, information) and paratouristic [66]. In agritourism there are to a large extent open innovations, i.e., ones in which the service provider does not rely solely on their own ideas or the results of their own research and development works, but uses external sources of innovation through cooperation with other entities [67].

According to Khanal and Mishra [68], innovations in agritourism can be implemented, for example, in educational, adventure and artistic farms. In rural areas, there are also initiatives in the field of social tourism (social farms) and health (e.g., occupational therapy on agritourism farms). Cooperation, including the establishment of thematic villages, tourist clusters, centers dealing with cultural animation and developing interests in various fields is also of great importance in the development of innovation in this industry [69].

The innovativeness of agritourism can have a direct impact on the level of development of the region [70]. Combining innovation in agritourism with regional development can create opportunities to reduce economic disparities between regions [71]. Regions creating and implementing innovations in agritourism are able to develop more dynamically than those that are deprived of them and have limited capacity to imitate and adapt [72].

The Ward method analyses presented in the article demonstrate that a dynamic development of agritourism can be accomplished in the regions with abundant nature qualities. The regions of the Podlaskie province are competitive to each other; so are the microenterprises, in that case the farms in those areas. It is very important to diversify the tourist offer and to adjust it to the needs of the tourist. In addition. the service provider should try to introduce new solutions if his or her farm is situated in typically agricultural areas and when the leading nature and landscape qualities are missing.

The distribution of the agritourism farms in the Podlaskie province depends on the landscape; the occurrence of waterbodies, lowlands, etc. In the lowlands and in the typically agricultural areas the number of beds is much lower. The landscape qualities are one of the distribution criteria for such facilities in that province. The key regions running such activity are the regions with poor industrialization and urbanization, with a low percentage of non-agricultural jobs, as well as the localities with available housing resources and favorable nature and landscape conditions. The index of competitive positioning of the farm and gaining an advantage in the agritourism services market presented in this article can be useful to determine the agritourism farm development also in terms of the innovations introduced.

The aspects of innovativeness are a field of economics referring to competitiveness. The topic presented in the study is new, not investigated yet—and thus, performing the original study was the key objective. A new methodology element in this article can be to organize the terms of innovation for the development of agritourism. It has also been essential to show the classification of the types of innovation in rural tourism and agritourism following the respective division criteria. The problems presented here, in the opinion of the article authors, are new and have a significant 
effect in demonstrating new trends in the development of agritourism. The topic covered is very extensive and the study has not been exhausted. Agritourism records dynamic changes and so following-up on the problem and performing similar studies, e.g., demonstrating the effect of the innovations introduced in agritourism on the profitability of agritourism farms, would be justifiable. It is also necessary to perform further studies due to the fact that the studies of innovations have rarely focused on agritourism farms. One can also investigate the examples of the innovations introduced on agritourism farms all across Poland, as well as in other countries of Europe or globally. It is mostly important to investigate the opinions of the agritourism farm owners on how they interpret the term "innovation" and the major types of innovation. It is worth making sure that the service providers do not mix the essence of innovation with their usual work, product development or marketing. Probably it is necessary to perform a qualitative study of small agritourism enterprises to answer the question adequately.

Author Contributions: Conceptualization, M.R. (Michał Roman), M.R. (Monika Roman), P.P.; data curation, M.R. (Monika Roman), M.R. (Michał Roman); formal analysis, M.R. (Michał Roman), M.R. (Monika Roman); methodology, M.R. (Monika Roman), M.R. (Michał Roman); resources, M.R. (Michał Roman), M.R. (Monika Roman); visualization, P.P., M.R. (Michał Roman), M.R. (Monika Roman); writing—original draft, M.R. (Monika Roman), M.R. (Michał Roman), P.P.; writing—review and editing, M.R. (Michał Roman), M.R. (Monika Roman), P.P.; supervision, M.R. (Michał Roman), M.R. (Monika Roman), P.P.; funding acquisition, M.R. (Michał Roman), M.R. (Monika Roman), P.P. All authors have read and agreed to the published version of the manuscript.

Funding: This research received no external funding.

Conflicts of Interest: The authors declare no conflict of interest.

\section{References}

1. Broccardo, L.; Culasso, F.; Truant, E. Unlocking Value Creation Using an Agritourism Business Model. Sustainability 2017, 9, 1618. [CrossRef]

2. Ciolac, R.; Adamov, T.; Ciolac, R.; Popescu, G.; Lile, R.; Rujescu, C.; Marin, D. Agritourism-A Sustainable Development Factor for Improving the 'Health' of Rural Settlements. Case Study Apuseni Mountains Area. Sustainability 2019, 11, 1467. [CrossRef]

3. Getz, D.; Page, J.S. The Business of Rural Tourism International Perspectives; International Thompson Publishing Company: Toronto, ON, Canada, 1997.

4. Ciolac, R.; Csosz, I.; Petroman, C.; Petroman, I.; Iancu, T.; Martin, S.; Marin, D.; Dincu, A.M. Research regarding agro-tourism stage in Apuseni Mountains area and capitalize of traditional products through this. Sci. Pap. Anim. Sci. Biotechnol. 2013, 45, 366-371.

5. Phillip, S.; Hunter, C.; Blackstock, K. A typology for defining agritourism. Tour. Manag. 2010, 31, 754-758. [CrossRef]

6. Roman, M. Innowacyjność Agroturystyki Jako Czynnik Poprawy Konkurencyjności Turystycznej Makroregionu Polski Wschodniej (Innovation of Agritourism as a Factor in Improving the Tourist Competitiveness of Eastern Poland Macroregion); Wydawnictwo SGGW: Warszawa, Poland, 2018.

7. Wojtkowiak, A. Agroturystyka szansą ożywienia terenów wiejskich. In Turystyka Wiejska, Ochrona Środowiska i Dziedzictwo Kulturowe Pogórza Dynowskiego (Rural Tourism, Environmental Protection and Cultural Heritage of the Dynów Foothills); Krupa, J., Soliński, T., Eds.; Wydawnictwo Związek Gmin Turystycznych Pogórza Dynowskiego: Dynów, Poland, 2011; Volume 30.

8. Ungureanu, C.D.; Brãgaru, C. The Agrotourism-A Vivid Chance for the Rural Life. In Ovidius University Annals, Economic Sciences Series; Ovidius University of Constantza: Constanța, Romania, 2011; Volume 1, pp. 2218-2222.

9. Tew, C.; Barbieri, C. The perceived benefits of agritourism: The provider's perspective. Tour. Manag. 2012, 33, 215-224. [CrossRef]

10. Ammirato, S.; Felicetti, A.M. The Agritourism as a Means of Sustainable Development for Rural Communities: A Research from the Field. Int. J. Interdiscip. Environ. Stud. 2014, 8, 17-29. [CrossRef]

11. Sonnino, R. For a 'Piece of Bread'? Interpreting Sustainable Development through Agritourism in Southern Tuscany. Sociol. Rural. 2004, 44, 285-300. [CrossRef] 
12. Gil Arroyo, C.; Barbieri, C.; Rich, S.R. Defining agritourism: A comparative study of stakeholders' perceptions in Missouri and North Carolina. Tour. Manag. 2013, 37, 39-47. [CrossRef]

13. Marin, D. Study on the economic impact of tourism and of agrotourism on local communities. Res. J. Agric. Sci. 2015, 47, 160-163.

14. Tracz, M.; Bajgier-Kowalska, M.; Uliszak, R. Rozwój agroturystyki w południowo-wschodniej Polsce-Ujęcie modelowe. Przeds. Eduk. 2018, 14, 329-344. [CrossRef]

15. Ciervo, M. Agritourism in Italy and the Local Impact Referring to Itria Valley. The Organic Firm "Raggio Verde" And Its Ecological Agritourism Project. Eur. Countrys. 2013, 5, 322-338. [CrossRef]

16. Rilla, E.; Hardesty, S.D.; Getz, C.; George, H. California agritourism operations and their economic potential are growing. Calif. Agric. 2011, 65, 57-65. [CrossRef]

17. Karabati, S.; Dogan, E.; Pinar, M.; Celik, L.M. Socio-Economic Effects of Agri-Tourism on Local Communities in Turkey: The Case of Aglasun. Int. J. Hosp. Tour. Adm. 2009, 10, 129-142. [CrossRef]

18. Cairol, D.; Coudel, E.; Knickel, K.; Caron, P.; Kroger, M. Multifunctionality of Agriculture and Rural Areas as Reflected in Policies: The Importance and Relevance of the Territorial View. J. Environ. Policy Plan. 2009, 11, 269-289. [CrossRef]

19. Brelik, A. Agroturystyka w zrównoważonym rozwoju województwa zachodniopomorskiego. Zeszyty Naukowe Uniwersytetu Szczecińskiego. Ekon. Probl. Ust. 2010, 52, 603-608.

20. Dudek, A.; Kowalczyk, A. Turystyka na obszarach chronionych—Szanse i zagrożenia. Pr. Stud. Geogr. 2003, 32, 117-140.

21. Topcu, E.D. Agri-Tourism: As a New Element of Country Planning; Basılmamış Yüksek Lisans Tezi; Ortadoğu Teknik Üniversitesi Fen Bilimleri Enstitüsü: Ankara, Turkey, 2007.

22. Gherman, C. Agritourism and food insecurity. A global threat. In Proceedings of the 15th International Conference Romanian Rural Tourism in the Context of Sustainable Development: Present and Prospects; Talaba, I., Haller, A.P., Herciu, M., Ungureanu, D., Eds.; Iascedillãi Branch of Romanian Academy: Vatra Dornei, Romania, 2013.

23. Petrović, M.; Blešić, I.; Ivolga, A.; Vujko, A. Agritourism impact toward locals' attitudes-An evidence from Vojvodina Province (Serbia). J. Geogr. Inst. Jovan Cvijic SASA 2016, 66, 105-123. [CrossRef]

24. Rogers, S. Innovation in food service technology and its strategic role. Int. J. Hosp. Manag. 2007, $26,899-912$. [CrossRef]

25. Schumpeter, J. Teoria Rozwoju Gospodarczego (Theory of Economic Development); Wydawnictwo PWN: Warszawa, Poland, 1960; Volume 104.

26. Sundbo, J.; Orfila-Sintes, F.; Sorensen, F. The innovative behaviour of tourism firms-Comparative studies of Denmark and Spain. Res. Policy 2007, 36, 88-106. [CrossRef]

27. Baggio, R. Technological Innovation in e-Tourism: The Role of Interoperability and Standards. In Tourism Management, Marketing and Development; Mariani, M.M., Baggio, R., Buhalis, D., Longhi, C., Eds.; Palgrave Macmillan: London, UK, 2014; pp. 42-43.

28. Zach, F.J.; Hill, T. Innovation in tourism destinations. Forum Sci. Oecon. 2017, 62, 196-207. [CrossRef]

29. Hall, C.M.; Williams, A.M. Tourism and Innovation; Routledge: Abingdon, UK, 2008.

30. Hall, C.M. Innovation and tourism policy in Australia and New Zealand: Never the twain shall meet? J. Policy Res. Tour. Leis. Events 2009, 1, 2-18. [CrossRef]

31. Hjalager, A.-M. A review of innovation research in tourism. Tour. Manag. 2010, 31, 1-12. [CrossRef]

32. Garau, C. Perspectives on Cultural and Sustainable Rural Tourism in a Smart Region: The Case Study of Marmilla in Sardinia (Italy). Sustainability 2015, 7, 6412-6434. [CrossRef]

33. Łebek, E.P.; Brambert, P. Innowacyjność w gospodarstwach agroturystycznych. Acta Univ. Lodz. Folia Geogr. Socio Oecon. 2018, 32, 125-138. [CrossRef]

34. Chiodo, E.; Fantini, A.; Dickes, L.; Arogundade, T.; Lamie, R.D.; Assing, L.; Stewart, C.; Salvatore, R. Agritourism in Mountainous Regions-Insights from an International Perspective. Sustainability 2019, 11, 3715. [CrossRef]

35. Eshun, G.; Tettey, C. Agrotourism development in Ghana: A study of its prospects and challenges at Adjeikrom Cocoa Tour Facility. Bull. Geogr. Socio Econ. Ser. 2014, 25, 81-99. [CrossRef] 
36. Sala, S. Wpływ procesów globalizacji na innowacje w agroturystyce. In Innowacyjność w Turystyce Wiejskiej a Nowe Możliwości Zatrudnienia na Obszarach Wiejskich (Innovation in Rural Tourism and New Employment Opportunities in Rural Areas); Kamińska, W., Ed.; Ministerstwo Rolnictwa i Rozwoju Wsi/Fundacja Programów Pomocy dla Rolnictwa FAPA: Warszawa, Poland, 2015; pp. 38-39.

37. Hjalager, A.M. Repairing innovation defectivness in tourism. Tour. Manag. 2002, 23, 465-474. [CrossRef]

38. Kofler, I.; Marcher, A.; Volgger, M.; Pechlaner, H. The special characteristics of tourism innovation networks: The case of the Regional Innovation System in South Tyrol. J. Hosp. Tour. Manag. 2018, 37, 68-75. [CrossRef]

39. Rønningen, M. Innovation in the Norwegian Rural Tourism Industry: Results from a Norwegian Survey. Open Soc. Sci. J. 2010, 3, 15-29. [CrossRef]

40. Raffai, C. Innovation in Rural Tourism: A Model for Hungarian Accommodation Providers. Manag. Mark. 2013, 8, 747-766.

41. Cosma, S.; Paun, D.; Bota, M.; Fleseriu, C. Innovation-A Useful Tool in the Rural Tourism in Romania. Procedia Soc. Behav. Sci. 2014, 148, 507-515. [CrossRef]

42. Hjalager, A.-M.; Kwiatkowski, G.; Larsen, M. Østervig Innovation gaps in Scandinavian rural tourism. Scand. J. Hosp. Tour. 2017, 18, 1-17. [CrossRef]

43. Hu, J. Technological Innovation Problems and Countermeasuresof Rural Tourism in Zhejiang: A Case Study of TengtouVillage, Ningbo City. Int. J. Educ. Bus. Manag. Learn. 2012, 2, 286-289. [CrossRef]

44. Stoican, M.; Varvaruc, D.; Camarda, A. The Romanian rural tourism. Actuality and perspectives in the context of innovation economy. Soc. Econ. Debates 2018, 7, 1-9.

45. Nair, V.; Hussain, K.; Lo, M.C.; Ragavan, N.A. Benchmarking innovations and new practices in rural tourism development: How do we develop a more sustainable and responsible rural tourism in Asia? Worldw. Hosp. Tour. Themes 2015, 7, 530-534. [CrossRef]

46. Miczyńska-Kowalska, M. Innovation in Agritourism as Perceived by Students of University of Life Sciences in Lublin. Acta Innov. 2017, 24, 53-64.

47. Cretu, R.C.; Cretu, R.F.; Stefan, P. Innovative and Sustainable Strategies in Romanian Tourism and Agritourism. In Proceedings of the 7th International Management Conference New Management for the New Economy, Bucharest, Romania, 7-8 November 2013; pp. 622-628.

48. Polukhina, A.N.; Rukomoinikova, V.P. Development of agritourism as an innovative approach to agricultural complex management in Russia. Worldw. Hosp. Tour. Themes 2018, 10, 458-466. [CrossRef]

49. Mohapatra, T. Agri-Tourism: An Innovative Supplementary Income-Generating Activity in Rural India. Int. J. Soc. Econ. Res. 2013, 3, 79. [CrossRef]

50. Sowmya, K.S.; Srikanth, C.D.; Sudha, M. Agri-Tourism: Innovative Income Generating Activity for Enterprising Farmers. Glob. J. Adv. Res. 2014, 1, 329-332.

51. Ahire, L.M.; Srinivasarao, C.; Kumar, S.V.; Reddy, V. An Innovative Concept to Earn an Extra Income from Agri Tourism-The Case of an Agri-Tourism Centres in Maharashtra, India. Int. Ref. Peer Rev. Index. Q. J. Sci. Agric. Eng. 2018, 7, 63-67.

52. Shumaev, V.A.; Morkovin, D.E.; Nikonorova, A.V.; Nezamaikin, V.N.; Yurzinova, I.L. Innovative aspects of agritourism project management. In Financial and Economic Tools Used in the World Hospitality Industry; Lumban Gaol, F., Filimonova, N., Maslennikov, V., Eds.; Taylor \& Francis: London, UK, 2018; pp. 241-247. ISBN 978-1-138-55397-2.

53. Roman, M.; Golnik, B. Current status and conditions for agritourism development in the Lombardy region. Bulg. J. Agric. Sci. 2019, 25, 18-25.

54. Ammirato, S.; Felicetti, A.M. The Potential of Agritourism in Revitalizing Rural Communities: Some Empirical Results. PRO-VE 2013. IFIP Advances in Information and Communication Technology. In Collaborative Systems for Reindustrialization; Camarinha-Matos, L.M., Scherer, R.J., Eds.; Springer: Berlin/Heidelberg, Germany, 2013. [CrossRef]

55. Pałka, E. Innowacje w gospodarstwach agroturystycznych Polski południowo-wschodniej (Innovations on agritourism farms in south-eastern Poland). Studia i Materiały. Misc. Oecon. 2015, 4, 73-88.

56. Ward, J.H. Hierarchical Grouping to Optimize an Objective Function. J. Am. Stat. Assoc. 1963, 58, $236-244$. [CrossRef]

57. Murtagh, F.; Legendre, P. Ward's Hierarchical Agglomerative Clustering Method: Which Algorithms Implement Ward's Criterion? J. Classif. 2014, 31, 274-295. [CrossRef]

58. Sarle, W.S. Cubic Clustering Criterion. In Technical Report A-108; SAS Institute Inc.: Cary, NC, USA, 1983. 
59. Caliński, T.; Harabasz, J. A dendrite method for cluster analysis. Commun. Stat. Theory Methods 1974, 3, 1-27. [CrossRef]

60. Roman, M.; Roman, M.; Niedziółka, A. Spatial Diversity of Tourism in the Countries of the European Union. Sustainability 2020, 12, 2713. [CrossRef]

61. Stastistical Analysis System (SAS). Available online: https://www.sas.com/pl_pl/software/university-edition/ download-software.html (accessed on 1 September 2019).

62. Data from the Central Statistical Office in Poland. Available online: https://bdl.stat.gov.pl/BDL/start (accessed on 10 April 2020).

63. Brscic, K. The impact of agro-tourism on agricultural production. J. Cent. Eur. Agric. 2006, 7, 559-563.

64. Karampela, S.; Papapanos, G.; Kizos, T. Perceptions of Agritourism and Cooperation: Comparisons between an Island and a Mountain Region in Greece. Sustainability 2019, 11, 680. [CrossRef]

65. Joshi, P.V.; Bhujbal, M.B. Agro-tourism a specialized rural tourism: Innovative product of rural market. Int. J. Bus. Manag. Tomorrow 2012, 2, 1-12.

66. Catalino, A.H.; Lizardo, M. Agriculture, environmental services and agro-tourism in the Dominican Republic. Electron. J. Agric. Dev. Econ. 2004, 1, 87-116.

67. Murai, A.M.; Shirke, G.; Sarap, N.S. Agri-Tourism in Konkan: An Innovative Enterprise for Farmers to Extra Income. Adv. Life Sci. 2016, 5, 10875-10880.

68. Khanal, A.R.; Mishra, A.K. Agritourism and off-farm work: Survival strategies for small farms. Agric. Econ. 2014, 45, 65-76. [CrossRef]

69. Van Sandt, A.; Low, S.A.; Thilmany, D. Exploring Regional Patterns of Agritourism in the U.S.: What's Driving Clusters of Enterprises? Agric. Resour. Econ. Rev. 2018, 47, 592-609. [CrossRef]

70. Budiasa, I.W.; Ambarawati, I.A. Community based agro-tourism as an innovative integrated farming system development model towards sustainable agriculture and tourism in Bali. J. Int. Soc. Southeast Asian Agric. Sci. 2014, 20, 29-40.

71. Mazilu, M.; Iancu, A. Agrotourism-An alternative for a sustainable rural development. Geotour 2006, 5, 162-165.

72. Hara, T.; Naipaul, S. Agritourism as a Catalyst for Improving the Quality of the Life in Rural Regions: A Study from a Developed Country. J. Qual. Assur. Hosp. Tour. 2008, 9, 1-33. [CrossRef]

(C) 2020 by the authors. Licensee MDPI, Basel, Switzerland. This article is an open access article distributed under the terms and conditions of the Creative Commons Attribution (CC BY) license (http://creativecommons.org/licenses/by/4.0/). 